\title{
CrimRxiv
}

\section{Men's Experiences of Violence in Intimate Relationships}

Marianne Inéz Lien, Jorgen Lorentzen

Published on: Jul 01, 2019

DOI: 10.21428/cb6ab371.89119669

License: Creative Commons Attribution 4.0 International License (CC-BY 4.0). 
